\title{
JUURNAL.RU
}

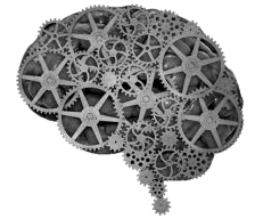

COMPANY GROUP "INTELLEKT"

\author{
Тришкина Ю.В., Асланян И.В. \\ Институт сервиса, туризма и дизайна (филиал) СКФУ в г.Пятигорске \\ Пятигорск, Россия
}

doi: 10.18411/lj2016-5-5-04

\section{Сравнительный анализ процесса сертификации в ведущих странах мира}

C процессом сертификации товаров сталкиваются все страны мира, включая и ведущие страны Европы. В соответствии с Законом о защите прав потребителей (ст. 7, п. 4), сертификация в нашей стране добровольная, но часть товаров подлежат обязательной сертификации в установленном порядке.

Суть сертификации для всех стран одна - это форма осуществляемого органом по сертификации подтверждения соответствия объектов требованиям технических регламентов, положениям стандартов, сводов правил или условиям договоров. Сертификация продукции является показателем качества и способствует росту спроса на товар в стране компании-производителя и на международном рынке. Оформление производителем сертификатов соответствия на свою продукцию повышает репутацию компании в глазах потребителей, так как доказывает высокое качество продукции и eе безопасность для окружающей среды и жизни людей.

Существуют различные схемы сертификации - это совокупность действий, принимаемых в качестве доказательства соответствия товара требованиям и нормам. Каждая из них рассчитана на определенную категорию товаров и услуг. Схемы сертификации определяют последовательность прохождения процедуры сертификации, не касаясь качества самой сертификации. 
Система государственных стандартов предусматривает несколько различных видов сертификации продукции. Наиболее распространенным является проведение сертификации у производителя продукциина основе заключаемого контракта на выпуск продукции или же отдельной партией продукции на основе контракта.

В целом, все виды сертификации можно поделить на добровольную и обязательную. Перечислим некоторые виды сертификатов:

- сертификат происхождения;

- сертификат пожарной безопасности (то есть пожарный сертификат);

- гигиенический сертификат и др..

- Кроме этого, существуют сертификаты соответствия, отвечающие не только европейским, но и международным нормам. К ним можно отнести:

- сертификация по стандарту OHSAS 18001;

- сертификаты Евро2, Евро3, Евро4 и Евро5;

- сертификация по стандарту ISO 14001;

- сертификация по стандарту ISO 9001.

Рассмотрим специфику проведения процедуры сертификации лишь в некоторых странах.

Национальная система сертификации в Германии объединяет ряд схем сертификации, ведущими из которых являются:

- А - система сертификации соответствия регламентам;

- A1 - система сертификации соответствия эталонам DIN;

- А2 - система сертификации VDE;

- А3 - система сертификации DVGW;

- $\mathrm{B}$ - система сертификации Германского института гарантии качества и маркировки RAL;

- $\mathrm{C}$ - система сертификации на знак GS промышленной технологии; 
- D - система надзора за соответствием строительных конструкций федеральным нормам;

- Е - система сертификации средств измерений и эталонов;

- F - система сертификации соответствия разделу 24 Германского промышленного законодательства [2].

Сертификация во Франции начала свое развитие с создания первого закона о знаке соответствия национальным стандартам NF. До сегодняшнего момента он претерпел множество изменений и дополнений, но все равно продолжает существовать. Ответственность за сертификацию была возложена на Французскую ассоциацию по стандартизации (AFNOR).

Оценка соответствия во Франции имеет несколько форм:

подтверждение соответствия европейским директивам;

заявление-декларация изготовителя о соответствии продукта европейскому стандарту;

добровольная сертификация на соответствие национальным стандартам Франции;

контроль безопасности продукции, находящейся в продаже.

Организационно сертификация основана на отраслевом принципе и постоянно взаимодействует состандартизацией системы как с точки зрения соответствия национальным стандартам, так и в разработке новых требований и норм.

Kроме AFNOR, сертификацией управляют органы государственного и отраслевого уровня: Французский центр внешней торговли (CNCE), Центр информация о нормах и технических регламентах (CINR), Союз электротехников (UTE) [3].

В Великобритании существует многофункциональная система сертификации. Самая большая система сертификации создана Британским институтом стандартов (БСИ). Длянее был разработан специальный знак соответствия британским стандартам.В основном сертификация осуществляется 
добровольно, но в некоторых областях правительство установило обязательные стандарты.

Совет по обеспечению качества БСИ назначает определенные функции Управлению по обеспечению качества БСИ QUAD. K этим функциям также относится и руководство работами по сертификации в рамках системы. В совет входят представители промышленности, торговли, потребительских организаций, правительства. Процедура сертификации продукции аналогична процедуре, применяемой во Франции.

В Соединенных Штатах, согласно законам по безопасности различных видов продукции, обязательной сертификации подлежит товар, на который принят государственный стандарт, а также продукция, закупаемая государством на внутреннем и внешнем рынках. Обязательная сертификация контролируется государственными органами.

Добровольная сертификация проводится по заявлению потребителей илиизготовителей продукции на предмет соответствия предлагаемого ими нормативного документа.

Федеральное правительство США утвердило три основные категории систем сертификации:

Первая категория является обязательной и относится к сертификации товаров и услуг по обеспечению безопасности.

- Вторая категория используется при обязательной и добровольной сертификации для товаров, которые потребляются в государственных учреждениях. К ней относятся программы по проверке образцов продукции и производств, заменяющие сплошной контроль.

- Третья категория используется для обязательной и добровольной сертификации.К ней относятся программы оценки качества и условий производства продукта для маркетинга. 
В Японии существуют три формы сертификации: обязательная сертификация, подтверждающая соответствие с требованиями законодательства; добровольная сертификация на соответствие национальным стандартам, которую проводят органы, уполномоченные правительством; добровольная сертификация, которая осуществляется частными органами по сертификации.

В Японии для каждого вида продукциисуществует определенная категория, которая характеризует степень опасности этой продукции для пользователя. Например, для электротехнических изделий установлены категории А и Б. Существуют различные схемы сертификации и знаки соответствия для каждой категории.

Для более опасных товаров (категория А) закон в Японии предусмотрел сертификацию третьей стороной, а для изделий категории Б - заявлениедекларацию изготовителя.

Для сертификации систем качества в Японии создана Японская ассоциация по сертификации систем качества (JAB).

Генеральный директор Японской ассоциации назначает аудиторов JAB, которые и осуществляют аккредитацию всех органов по сертификации и всех организаций, занимающихся подготовкой аудиторов. Центр сертификации систем качества Японской ассоциации по стандартизации (JSA-Q), Центр по контролю газового оборудования (ЛА-QА), Центр сертификации систем качества Ассоциации по безопасности сосудов, работающих под давлением (KHK-QA) и др. аккредитованы именно аудиторами JАВ [1].

В Российской Федерации для реализации товара необходимы следующие типы сертификации:

- Сертификат соответствия ГОСТ Р;

- Декларация о соответствии в системе ГОСТ Р;

- Сертификат соответствия техническому регламенту;

- Декларация о соответствии техническому регламенту;

- Свидетельство о государственной регистрации. 
Порядок сертификации продукции и оформления сертификатов включает в себя следующие этапы:

- подача заявки в центр сертификации;

- предоставление необходимого пакета документов;

- проведение сертификационных лабораторных испытаний;

- оформление гигиенического сертификата (на некоторые виды продукции);

- оформление сертификата соответствия или декларации о соответствии;

Сертификация продукции в России может занимать в среднем от одной до нескольких недель. Кстати, под пристальным вниманием проверяющей службы оказывается не только конечный продукт, но и вся производственная линия предприятия. Изделия из пластмасс должны подвергаться особенно жесткой проверке для выдачи необходимого сертификата, поскольку те же многочисленные игрушки производятся не отечественными, а различными недобросовестными зарубежными компаниями из Китая или Кореи.

История развития системы сертификации в каждой стране имеет свою дату отсчета. В Германии это были - двадцатые годы прошлого века. В Британии - 20-30 годы. В России же система сертификации начала формироваться в 80-90 годы двадцатого века. Несмотря на столь позднее начало, Российская Федерация довольно быстро вышла на международный уровень сертификации товаров и в настоящий момент незаметно какого-либо отставания в развитии системы сертификации в России. Сравнивая систему сертификации в различных странах, можно заметить их схожесть в целом принципе построения. При этом в каждой стране присутствуют какие-либо свои отличительные характеристики.

Развитие сертификации бежит огромными скачками. За небольшой отрезок времени человечество добилось колоссальных результатов в этой области. Каждой стране присуща своя огромная и систематизированная 
структура сертификации, впечатляющая воображение своей четкостью и гармоничностью, при этом все страны объединены в международную систему, что позволяет облегчить множество организационных вопросов.

\section{Литература:}

1. Ефимов В.В., Самсонова М.В. Управление процессами. Ульяновск: УлГТУ, 2008. - 222 с.

2. Метрология. Стандартизация. Сертификация. Под ред. В.М. Мишина. М.: Юнити-Дана, 2012. - 946 с.

3. Колчков В.И. Метрология. Стандартизация. Сертификация. М.: Форум, 2015. $-432 \mathrm{c}$. 